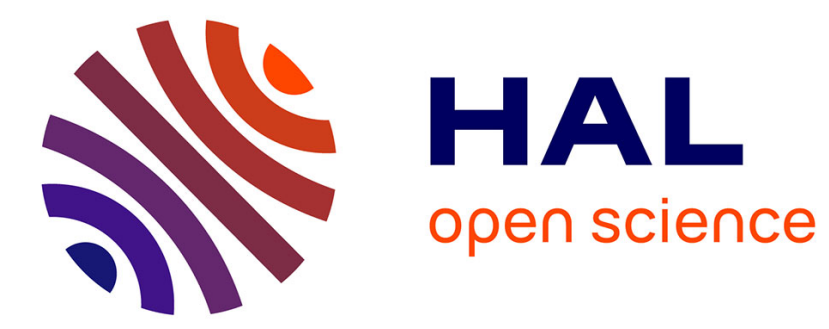

\title{
How to Quickly Get a Job? The Transition from Higher Education to French Labour Market by a Survival Model
}

Carlos Pestana Barros, Jean-Pascal Guironnet, Nicolas Peypoch

\section{To cite this version:}

Carlos Pestana Barros, Jean-Pascal Guironnet, Nicolas Peypoch. How to Quickly Get a Job? The Transition from Higher Education to French Labour Market by a Survival Model. Applied Economics, 2010, 43 (4), pp.439. 10.1080/00036840903166251 . hal-00582299

\section{HAL Id: hal-00582299 \\ https://hal.science/hal-00582299}

Submitted on 1 Apr 2011

HAL is a multi-disciplinary open access archive for the deposit and dissemination of scientific research documents, whether they are published or not. The documents may come from teaching and research institutions in France or abroad, or from public or private research centers.
L'archive ouverte pluridisciplinaire HAL, est destinée au dépôt et à la diffusion de documents scientifiques de niveau recherche, publiés ou non, émanant des établissements d'enseignement et de recherche français ou étrangers, des laboratoires publics ou privés. 


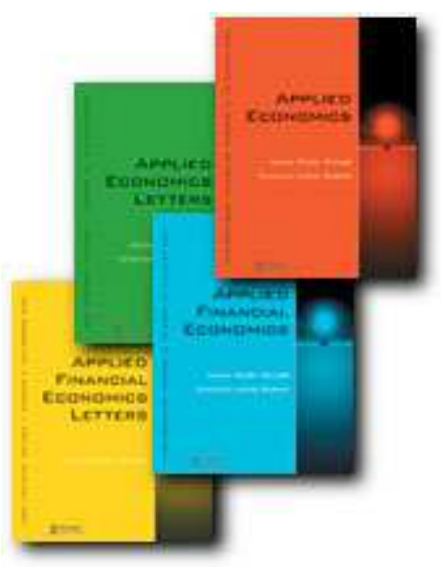

\section{How to Quickly Get a Job? The Transition from Higher Education to French Labour Market by a Survival Model}

\begin{tabular}{|c|c|}
\hline Journal: & Applied Economics \\
\hline Manuscript ID: & APE-08-0130.R1 \\
\hline Journal Selection: & Applied Economics \\
\hline $\begin{array}{r}\text { Date Submitted by the } \\
\text { Author: }\end{array}$ & 19-Nov-2008 \\
\hline Complete List of Authors: & $\begin{array}{l}\text { Barros, Carlos; Technical University of Lisbon, Instituto Superior de } \\
\text { Economia e Gestão } \\
\text { Guironnet, Jean-Pascal; LAMETA, University of Montpellier } 1 \\
\text { Peypoch, Nicolas; GEREM, Université de Perpignan }\end{array}$ \\
\hline JEL Code: & $\begin{array}{l}\text { C41 - Duration Analysis < C4 - Econometric and Statistical } \\
\text { Methods: Special Topics < C - Mathematical and Quantitative } \\
\text { Methods, I21 - Analysis of Education < I2 - Education < I - Health, } \\
\text { Education, and Welfare, J21 - Labor Force and Employment, Size, } \\
\text { and Structure < J2 - Time Allocation, Work Behavior, and } \\
\text { Employment Determination/Creation < J - Labor and Demographic } \\
\text { Economics }\end{array}$ \\
\hline Keywords: & Education, France, Survival models \\
\hline
\end{tabular}

\section{s ScholarONE" \\ Manuscript Central}




\title{
How to Quickly Get a Job? The Transition from Higher Education to French Labour Market by a Survival Model
}

\author{
Carlos P. Barros, Jean-Pascal Guironnet`and Nicolas Peypoch ${ }^{\ddagger}$
}

January, 2008

This version: November, 2008

\begin{abstract}
This article analyses how long former university students stay unemployed, when searching for the new employment after leaving of the French higher education. Cox duration models are used to account for the proportional hypothesis. The main result of this paper is that the worker's recruitment is based more on the choice of the faculty of initial training than the educational level attainment. Some policy implications are derived from our results to give some recommendations for individual job search and policy-makers in education.
\end{abstract}

JEL: C41, I21, J21.

Keywords: Education, France, survival models.

*ISEG, Technical University of Lisbon, Rua Miguel Lupi, 20, 1249-078 Lisbon, Portugal. cbarros@iseg.utl.pt

${ }^{\dagger}$ CREUSET-CNRS, University of Jean Monnet Saint-Etienne, 6 rue Basse des Rives, F-42023 Saint-Etienne Cedex 2, France. jean.pascal.guironnet@univ-st-etienne.fr

$\ddagger$ IAE, GEREM, LAMPS, University of Perpignan, 52 Avenue Paul Alduy, F-66860 Perpignan Cedex,France.peypoch@univ-perp.fr 


\section{Introduction}

The empirical study of the unemployment of the leavers of higher education can benefit from the application of event history analysis. This technique focuses on the factor effects that determine the length of time until the occurrence of some event. This technique has been recently used in the unemployment duration topic (Grilli 2006; Collier, 2005; Haurin and Sridhar, 2003; Gonzalo, 2002), in international relations (e.g. Barros, et al. 2005), corporate finance (Leung, et al. 2003) and industry (Requena-Vicente and Walker, 2005).

This paper analyses the determinants of unemployment duration after the leaves of higher education. Although this is not the first paper applying event history analysis to the unemployment duration, our approach is unique since we look at unemployment after leaving university. Hence, professional insertion of graduates is studied with a special attention in respect to the overeducation issues. Such attention has never been studied in the works on unemployment duration whereas the extent of schooling surplus increases in the majority of developed country (Sloane, 2003). The motivation for this research is to know what the covariates explaining unemployment duration are. Unemployment duration may depend on the university course taken, and some individual characteristics. Therefore, it is important to ascertain the covariates which explain the unemployment duration of the leavers of higher education.

The paper contributes to the related literature in four ways. First, by adopting a panel data framework, it uses a hazard model, previously applied in education by Audas et al. (2005). Second, it studies unemployment among graduates of higher education, an issue that so far has not inspired much research in Europe, despite its increasing importance. Third, it analyses data from one of the major European economy which, in turn, allow some broader generalizations. Finally, it adopts the Cox model since the proportional hypothesis is accepted. ${ }^{1}$

This paper is organised as follows. Section 2 summarizes the relevant literature about our topic research. Section 3 describes the contextual setting, i.e. the higher education and

\footnotetext{
${ }^{1}$ There are two types of survival models, the Cox proportional hazard model which assumes that events evolve proportional along the period and the accelerated hazard models which assume that the events accelerated along the period.
} 
labour market dynamics in France. Section 4 presents the research design, with details about the methodology and the tested hypothesis in our empirical specification. Section 5 presents the data and the results. Section 6 discusses the results and, finally, section 7 concludes.

\section{Literature Survey}

Following human capital theory, a higher level of education should increase the probability to get a job. However in the seventies, some rival theories question this initial assumption (e.g. "signal theory" of Spence, 1973). Hence, empirical studies have showed an excess of education offer which produces dismishing return of education (Freeman, 1976). Today, it seems to be attractive to search the incidences of this surplus schooling in the professional insertion of graduates. Therefore, this paper proposes to study unemployment duration of the leavers of higher education by a survival model in taking surplus schooling into account.

Studies on unemployment duration are common on the labour market, (Tribó, 2005; Cueto and Mato, 2006), but research linking education and duration is scarce (Audas, et al. 2005). The present research follows this tradition and focuses on higher education level. Two specifications of survival models are used: First, single risk model (e.g. Kirby, et al. 1999) versus competing risk models (e.g. Stinebrickner, 2002). Second, proportional hazard models (Audas et al. 2005; Imazeki, 2005) versus accelerated hazard models (e.g. VegaCervera and Gordillo, 2001). In this research topic, empirical literature tries mainly to identify the unobserved individual heterogeneity in duration model with the first seminal work of Lancaster (1979). Such approach has been considered by Addison and Portugal (2003). More recently, Eyal and Beenstock (2008) have found mixed results on the effect of vocational training on unemployment duration if we take - or not - self-selectivity into account.

Relative to the issues of duration models used in education, Audas, et al. (2005) analyse youth unemployment in Hungary with a Cox proportional hazard. The length to first get a job after graduation, which is directly related to the present research, was positive for female living in the capital and is negative for other covariates. Another paper on education duration models (Lassibile and Gómez, 2008) analyses the drop-out behaviour of Spanish students in 
higher education in comparing homogenous discrete survival model with a discrete frailty, or heterogenous survival model. They conclude that academic preparedness and age enrolment are indicators of drop-out. Imazeki (2005) analyses USA teacher's transfers and their exits with a Cox model. Vanderberghe (2000) studies the leaving teaching in Belgium with Cox and Weibull duration models.

\section{The Labour Market and Higher Education in France}

In France, the possibility to follow higher studies has largely improved in the eighties. For example, graduates of higher education represented $36 \%$ of the leavers of educational system in 2000 whereas twenty years ago the proportion was around $15 \%$. Hence, education supply was largely diversified ${ }^{2}$ with the "orientation law on education" in 1989 which consisted in diversifying schooling courses to encourage more students to invest longer in their schooling courses. Furthermore, the new "Fillon law" forecast today to lead $50 \%$ of graduates in higher education. Over these two last decades, education offer has been largely developed but one can wonder what has been happening with the demand side of labour market.

Since the late of eighties, GNP rates had risen and fallen in a recession due to the Gulf war. Unemployment rates rose from 1982 to 1990. In 1996, business activities were also prosperous but the integration difficulties of young people into the job market increased: The unemployment rate of young graduates, three years after leaving of college, is estimated at $9.71 \%$ in 1999 . This high number of unemployed graduates is especially significant since it should produce a "skill bumping effect". Consequently, an overeducation variable is introduced to take schooling surplus into account: Overeducation phenomenon influences probably the transition of higher education to the labour market (see next section for more details).

To assess worker mismatches objectively, one must compare an analysis of the skills that are a priori required for a given job and the occupation-type for which initial training prepares the holder. Consequently, one must use a "matches grid" between degrees and occupations. Thus, overeducation measurement is based on a comparison between the individual level of

\footnotetext{
${ }^{2}$ In particular in the engineering schools.
} 


\section{Research Design}

In this study, the unemployment duration of the leavers of higher education is analysed using a survival modeling approach (Cox and Oakes, 1984). The duration of an event is the time elapsed until a certain event occurs or is completed. The length of unemployment after leaving of higher education are analysed using survival models that are based on the fact that the error distribution, in this context, must be skewed to the right. The survival model regresses the duration of an activity on covariates alongside a traditional regression model. The most straightforward way to describe the survival in a sample is to compute the "Life Table". Multivariate models exist to analyse the survival models taking into account the non-normality distribution of the month number that the respective individual remains unemployed. Therefore, survival models are alternative models to ordinary least squares (OLS) regression, based on the fact that OLS regression cannot accommodate skewed regressions.

Two issues must be addressed when analysing survival models: i) identification of the data set (i.e., cross-section vs. panel data); and ii) censoring of the data. With regard to the first issue, the present study adopts a panel data analysis. Therefore, time-variant modeling - known as Cox's time-dependent proportional hazard models - is adopted. In terms of censoring, Gokovali et al. (2006) concludes that questionnaire data is uncensored because individuals are observed at the end of the event. A survival time is described as

\footnotetext{
${ }^{3}$ See Guironnet and Peypoch (2007) for a survey on overeducation measurements.

${ }^{4}$ This method, much used in the United States, is essentially based on the "Dictionary of occupational Titles".
} 
censored when there is a follow-up time but the event has not yet occurred or is not known to have occurred, when the data is gathered. For example, if the student gets an employment immediately after the leaves of higher education, the duration is uncensored. Furthermore, if individuals obtain a job later, but they are already hired when the data is gathered, there is no censorship. Censorship can appears for students who search for a job and they are not hired when the data is gathered.

Given these considerations, the following estimating strategy was followed. First, the traditional Cox proportional hazard model for single-event data was adopted, assuming that events are likely to be independent. As the theory relating education and employment is mixed, we opt for the Cox model, which does not rely on any assumption concerning the nature and shape of the underlying survival distribution. However, the Cox model has two assumtions. First, the proportional assumption which means that the ratio of the hazard function for two given observations does not depend on time. Second, there is a log-linear relationship between the independent variable and the underlying hazard function. When adopting a Cox model, the test for the proportional hypothesis is mandatory. In the present research, we adopt the "Schoenfeld tests". Following this approach, it is concluded that while the chi-square global test is statistical significant: we reject the null hypothesis and we assume that the independent variable is significantly related to survival times. In this case, the Cox's proportional hazard model with time-dependent covariates is adopted. For this model, the hazard is specified as:

$$
h_{i k}\left(t \mid X_{i k}\right)=h_{0 k}\left(t-t_{k-1}\right) \exp \left(\beta_{i k}\right)
$$

where $k$ denotes the event number, and $i$ is the individual, $h_{0 k}$ is the baseline hazard and varies by event number, $X$ is a vector of covariates which can be time dependent and $\beta$ is a vector of parameters. The parameters are estimated using partial likelihood given by:

$$
L(\beta)=\Pi_{i=1}^{n} \Pi_{k=1}^{K_{i}}\left(\frac{\exp \left(\beta X_{i k}\right)}{\sum_{i=1}^{n} \sum_{k=1}^{K_{i}} Y_{i k} \exp \left(\beta X_{i k}\right)}\right)^{\delta_{i k}},
$$

where $\delta$ is a censoring indicator equals to one if observed and zero if censored and $Y$ is a risk indicator which is equals to one if the individual is at risk for the current event and zero otherwise. The model is estimated using maximum likelihood. 
In the Weibull model the baseline is defined by:

$$
h_{0 k}\left(t-t_{k-1}\right)=\alpha_{k}\left(t-t_{k-1}\right)^{\alpha_{k}-1},
$$

where the time dependent parameter, $\alpha_{k}$, is estimated separately for each event. Both models are estimated through maximum likelihood.

Following this econometric model, the focus of our paper is to study French unemployment duration in 1999, in respect to the individual educational attainment. This unemployment duration of graduates of higher education depends on two critical factors: The individual's education specific skills and the characteristics of the local labour market (preferences for a certain type of skill are likely to differ between the firms). The following hypotheses are tested with the econometric model described above:

[H1] In the beginning of the professional career, educational level is the main determinant of worker's insertion. This hypothesis is tested with the "NAE" (number of educational years) variable in higher education, Gonzalez and Hilmer 2006). The associated coefficient of this variable is expected to be negative and therefore to decrease the unemployment duration. [H2] Higher starting wages should decrease unemployment duration. This assumption is established on logarithm of the wage ("Log-Wages" variable), assumed to be negative and therefore contributing to decrease unemployment duration. However, one can expect that this link is not obvious on the French labour market (Bazen and Martin, 1991).

[H3] Women are more exposed to unemployment. This assumption can be explained by "Gender" variable, Prieto-Rodriguez and Rodriguez-Gutierrez (2000). This latter should be positive and statistical significant to imply that men have higher probability to get a job (Shauman, 2005).

[H4] Overeducation phenomenon must decrease unemployment duration. A worker that accepts to be mismatched increases this probability to get a job, increasing the choice number in the range of job available, Battu, Belfield and Sloane(1999). This hypothesis can be tested by "Over" variable and the associated coefficient should be negative.

[H5] A public career prospect should increase unemployment duration. The private sector can recruit more quickly - due to its more flexible nature - a worker that the public sector recruits by competitive exam (Russo, Gorter, Schettkat, 2001). This hypothesis can be tested by 
"Public" variable.

[H6] Job search increases the probability to find a job. One explanation is that this behaviour is an indicator of the individual motivation (Van Hooft et al. 2005). This assumption can be tested by "Search" variable.

[H7] The historic of professional career can be interpreted as a signal (Spence, 1973) of worker's productivity - or motivation - by employers. This assumption can be tested with the historic of previous job characterized by "Past-Job" variable. In the same sense, to follow a stage ("Stage" variable) during this schooling should increases the probability to quickly get a job (Heywood and Wei, 2004). Therefore, this hypothesis is tested with the two following variables: Past-job and Stage.

[H8] The training faculty is a major determinant of the individual's career (Diebolt and El Murr, 2003). Some specialties, needed by labour market for a given time period, increase the probabilities to find a job. This phenomenon can be viewed with "ES", "NS" and "HS" variables.

[H9] If one of the parents works as an executive, children have higher probabilities to find a job (O'Regan and Quigley, 1993). An executive parent should favour her child's employability by her connections. This latter assumption can be tested by "EF" and "EM" variables.

[H10] Vocational training gives some advantages in the professional insertion. These courses are shorter and should be more adapted to the demand of labour market, Andrén and Andrén (2006), Budria and Pereira (2007). However, this hypothesis seems to be partially accepted on the Israel case (Eyal and Beenstock, 2007). In our case, this hypothesis is tested by "VD" variable.

[H11] It is easier to find a job in small firms. Large firms can demand more specific skills to do the job than smaller firms. One explanation is that large firms set more precisely skill matches for the job than small firms (Dupray, 2001). We tested this assumption by "Medium Firm" and "Large Firms" variables.

[H12] Individuals that have done their national service in army have more difficulties to find a job. In this case, serviceman cannot immediately prospect for a job and they are set back in their professional career (Anderson, Halcoussis and Tollison, 1996; Warner and Negrusa, 2005). This assumption is tested by "Army" variable. 


\section{$5 \quad$ Data and Findings}

Our analysis of employment duration is based on the Céreq ("Centre d'Étude et de Recherches sur les Qualifications") data. The database of 1996 is constructed by investigating a graduate cohort, three years after students leave (i.e. in 1999). The answers of each individual surveyed are collected in this database, named "Devenir des diplômés de l'enseignement supérieur". These data are representative of the leavers of higher education in France: for example, the male number of the leavers is effectively higher -around $55 \%$ - than female (see table 1 for a presentation of the characteristics of the data used in the analysis) for the higher education. These longitudinal data provides extensive information on graduate careers. Our study is based on leavers of bachelor and master courses, technological universities, engineer graduates, business schools accredited by the government, and PhD students. Medical, paramedical, social or artistic training and graduates of foreign nationalities are not interviewed. Our research topic is to study the professional insertion of the leavers of higher education. Consequently, we excluded unemployed graduates after three years of the leaves of educational system, people of more than 35 years and part-time workers. Our objective is to study a durable professional insertion of the leavers of higher education.

Overall, we retained for 1999 a sample of 1,871 leavers of higher education. Longitudinal information for homogeneous variable is collected at three points of time of the calendar (i.e. one year, two years and third years after leaving the higher education system). 
Table 1. Characteristics of the Variables

\begin{tabular}{|c|c|c|c|c|c|c|}
\hline Variable & Description & Role & $\operatorname{Min}^{a}$ & $\operatorname{Max}^{b}$ & Mean & Std. Dev \\
\hline Unemploy & $\begin{array}{l}\text { Number of months unemployed after } \\
\text { higher education graduating. }\end{array}$ & Dependent variable & 0 & 26 & 1.91 & 3.32 \\
\hline NAE & $\begin{array}{l}\text { Number of educational years } \\
\text { in higher education. }\end{array}$ & $\begin{array}{l}\text { Variable testing } \\
\text { hypothesis } 1\end{array}$ & 2 & 8 & 3.81 & 1.471 \\
\hline Log-Wages & $\begin{array}{l}\text { Logarithm of the salary of } \\
\text { the individual. }\end{array}$ & $\begin{array}{l}\text { Variable testing } \\
\text { hypothesis } 2\end{array}$ & 8.517 & 10.819 & 8.959 & 0.3 \\
\hline Gender & $\begin{array}{l}\text { Dichotomic variable which is } \\
\text { one for males and zero for females. }\end{array}$ & $\begin{array}{l}\text { Variable testing } \\
\text { hypothesis } 3\end{array}$ & 0 & 1 & 0.548 & 0.497 \\
\hline Over & $\begin{array}{l}\text { Dichotomic variable coded } 1 \text { if } \\
\text { the individual is rated overeducated. }\end{array}$ & $\begin{array}{l}\text { Variable testing } \\
\text { hypothesis } 4\end{array}$ & 0 & 1 & 0.408 & 0.491 \\
\hline Public & $\begin{array}{l}\text { Dichotomic variable which is one } \\
\text { for public career and zero elsewhere. }\end{array}$ & $\begin{array}{l}\text { Variable testing } \\
\text { hypothesis } 5\end{array}$ & 0 & 1 & 0.193 & 0.395 \\
\hline Search & $\begin{array}{l}\text { Dichotomic variable which is one if the individual } \\
\text { searched for a job and zero elsewhere. }\end{array}$ & $\begin{array}{l}\text { Variable testing } \\
\text { hypothesis } 6\end{array}$ & 0 & 23 & 1.458 & 3.132 \\
\hline Past-Job & $\begin{array}{l}\text { Dichotomic variable which is one if the individual } \\
\text { had past jobs during this schooling. }\end{array}$ & $\begin{array}{l}\text { Variable testing } \\
\text { hypothesis } 7\end{array}$ & 0 & 1 & 0.048 & 0.215 \\
\hline Stage & $\begin{array}{l}\text { Coded one if the individual have follow } \\
\text { a stage during this schooling. }\end{array}$ & $\begin{array}{l}\text { Variable testing } \\
\text { hypothesis } 7\end{array}$ & 0 & 1 & 0.872 & 0.334 \\
\hline $\mathrm{ES}$ & $\begin{array}{l}\text { Dichotomic variable coded } 1 \text { if training } \\
\text { specialities is exact science. }\end{array}$ & $\begin{array}{l}\text { Variable testing } \\
\text { hypothesis } 8\end{array}$ & 0 & 1 & 0.351 & 0.477 \\
\hline NS & $\begin{array}{l}\text { Dichotomic variable coded } 1 \text { if training } \\
\text { specialities is natural science. }\end{array}$ & $\begin{array}{l}\text { Variable testing } \\
\text { hypothesis } 8\end{array}$ & 0 & 1 & 0.072 & 0.258 \\
\hline HS & $\begin{array}{l}\text { Dichotomic variable coded if training } \\
\text { specialities is human science. }\end{array}$ & $\begin{array}{l}\text { Variable testing } \\
\text { hypothesis } 8\end{array}$ & 0 & 1 & 0.106 & 0.308 \\
\hline $\mathrm{EF}$ & $\begin{array}{l}\text { Dichotomic variable coded } 1 \text { if the } \\
\text { father's profession is executive. }\end{array}$ & $\begin{array}{l}\text { Variable testing } \\
\text { hypothesis } 9\end{array}$ & 0 & 1 & 0.35 & 0.477 \\
\hline EM & $\begin{array}{l}\text { Dichotomic variable coded } 1 \text { if the } \\
\text { mother's profession is executive. }\end{array}$ & $\begin{array}{l}\text { Variable testing } \\
\text { hypothesis } 9\end{array}$ & 0 & 1 & 0.144 & 0.351 \\
\hline VD & $\begin{array}{l}\text { Dichotomic variable coded } 1 \text { if the } \\
\text { individual has a vocational degree. }\end{array}$ & $\begin{array}{l}\text { Variable testing } \\
\text { hypothesis } 10\end{array}$ & 0 & 1 & 0.417 & 0.493 \\
\hline Medium-Firm & $\begin{array}{l}\text { Dichotomic variable coded } 1 \text { if the individual works } \\
\text { in a firm size between } 199 \text { and } 499 \text { employees. }\end{array}$ & $\begin{array}{l}\text { Variable testing } \\
\text { hypothesis } 11\end{array}$ & 0 & 1 & 0.363 & 0.481 \\
\hline Large-Firm & $\begin{array}{l}\text { Dichotomic variable coded } 1 \text { if the individual works } \\
\text { in a firm of more than } 499 \text { employees. }\end{array}$ & $\begin{array}{l}\text { Variable testing } \\
\text { hypothesis } 11\end{array}$ & 0 & 1 & 0.204 & 0.403 \\
\hline Army & $\begin{array}{l}\text { Coded one if the individual have } \\
\text { do this army obligation. }\end{array}$ & $\begin{array}{l}\text { Variable testing } \\
\text { hypothesis } 12\end{array}$ & 0 & 1 & 0.155 & 0.362 \\
\hline
\end{tabular}

${ }^{a}$ Min - Minimum; ${ }^{b}$ Max - Maximum 
We present a number of different duration models for comparative purposes. The dependent variable for each specification is unemployment (measured in months). The estimated coefficients are always in the proportional-hazard metric. Model 1 (M1) is the Cox proportional hazard model. Model 2 (M2) is Cox proportional model with clustering around time, to verify if there are any types of cluster around the variable gender. Model 3 (M3) is the Cox model with stratification by gender to test whether the relationship between the independent variables is different among groups. Model 4 (M4) is the Cox's proportional hazard model with time-dependent covariates, and (M5) is the Weibull model with time, that is presented for comparative purpose.

Table 2. Estimation Results

\begin{tabular}{|c|c|c|c|c|c|c|c|c|c|c|}
\hline & \multicolumn{2}{|c|}{ M1 } & \multicolumn{2}{|c|}{ M2 } & \multicolumn{2}{|c|}{ M3 } & \multicolumn{2}{|c|}{ M4 } & \multicolumn{2}{|c|}{ M5 } \\
\hline & Coeff. & s.e. & Coeff. & s.e.(2) & Coeff. & s.e.(2) & Coeff. & s.e.(2) & Coeff. & s.e.(2) \\
\hline NAE & 0.010 & 0.023 & 0.010 & 0.017 & 0.005 & 0.020 & 0.012 & 0.024 & 0.018 & 0.001 \\
\hline Log-Wages & -0.115 & 0.099 & -0.115 & 0.127 & -0.106 & 0.111 & -0.304 & 0.143 & -0.026 & 0.076 \\
\hline Gender & 0.032 & 0.059 & 0.032 & 0.051 & 0.028 & 0.037 & 0.014 & 0.059 & 0.022 & 0.043 \\
\hline Over & 0.095 & 0.056 & 0.095 & 0.055 & 0.098 & 0.057 & 0.284 & 0.091 & 0.052 & 0.045 \\
\hline Public & -0.023 & 0.069 & -0.023 & 0.045 & -0.012 & 0.046 & -0.003 & 0.070 & -0.020 & 0.051 \\
\hline Search & -0.216 & 0.06 & -0.216 & 0.012 & -0.227 & 0.012 & -0.231 & 0.006 & -0.119 & 0.003 \\
\hline Past-Job & -0.101 & 0.108 & -0.101 & 0.100 & -0.100 & 0.100 & -0.144 & 0.389 & -0.057 & 0.072 \\
\hline Stage & -0.130 & 0.086 & -0.130 & 0.044 & -0.116 & 0.039 & 0.326 & 0.086 & 0.086 & 0.045 \\
\hline ES & 0.198 & 0.057 & 0.198 & 0.068 & 0.207 & 0.071 & 0.210 & 0.057 & -0.115 & 0.040 \\
\hline NS & -0.190 & 0.091 & -0.190 & 0.067 & -0.190 & 0.074 & -0.115 & 0.166 & -0.121 & 0.041 \\
\hline HS & -0.409 & 0.096 & -0.409 & 0.065 & -0.422 & 0.058 & -0.398 & 0.097 & -0.221 & 0.084 \\
\hline $\mathrm{EF}$ & 0.018 & 0.054 & 0.018 & 0.082 & 0.013 & 0.083 & -0.146 & 0.094 & 0.012 & 0.039 \\
\hline EM & -0.012 & 0.115 & -0.012 & 0.097 & -0.047 & -0.115 & 0.104 & 0.123 & 0.033 & 0.050 \\
\hline VD & 0.155 & 0.059 & 0.155 & 0.040 & 0.164 & 0.036 & 0.139 & 0.056 & 0.088 & 0.036 \\
\hline Medium-Firm & 0.059 & 0.054 & 0.059 & 0.008 & 0.062 & 0.006 & 0.036 & 0.054 & 0.013 & 0.041 \\
\hline Large-Firm & 0.244 & 0.066 & 0.244 & 0.026 & 0.247 & 0.021 & 0.226 & 0.066 & 0.109 & 0.042 \\
\hline Army & -0.421 & 0.066 & -0.421 & 0.153 & -0.407 & 0.150 & -0.458 & 0.066 & -0.260 & 0.050 \\
\hline constant & - & - & - & - & - & - & - & - & 0.731 & 0.661 \\
\hline$L n P$ & - & - & - & - & - & - & - & - & 0.615 & 0.026 \\
\hline- & - & - & - & - & - & - & Time dependent & covariates & - & - \\
\hline Log-Wages & - & - & - & - & - & - & -0.383 & 0.105 & - & - \\
\hline Over & - & - & - & - & - & - & -0.317 & 0.065 & - & - \\
\hline$N S$ & - & - & - & - & - & - & 0.218 & 0.116 & - & - \\
\hline Stage & - & - & - & - & - & - & -0.367 & 0.108 & - & - \\
\hline$E F$ & - & - & - & - & - & - & -0.129 & 0.069 & - & - \\
\hline$E M$ & - & - & - & - & - & - & 0.161 & 0.090 & - & - \\
\hline$L L$ & -11545.31 & - & -11545.31 & - & -10257.60 & - & -11515.41 & - & $-1589,9$ & - \\
\hline Nobs & 1871 & - & 1871 & - & 1871 & - & 1871 & - & - & - \\
\hline
\end{tabular}


Values in bold are statistically significant at $1 \%$ level

(1) - All models were estimated in Stata 9

(2) - Robust standard errors

$L L$ - Log Likelihood

Cox's proportional hazard model with time-dependent covariates is the model of reference, based in the "Schoenfeld tests". On all models, results are quite similar in their main effects. Given the model specification, positive values for the parameters imply that the unemployment duration increases with increasing values in the respective variable. On the opposite, a negative value for the parameters means a negative relationship. Results across the four models demonstrate that the parameters have the same signs for all variables. On the basis of the log likelihood statistic of the models and the "Schoenfeld tests", ${ }^{5}$ the Cox's model with time-dependent covariates is the reference model. The rationale for this result is that while accepting the proportional hypothesis, timedependent proportionality exists for some variables. Weibull time-dependent model is presented for comparative purpose. The signs of the variables and the significance level in the Cox model and Weibull model are similar. The results of table 2 are discussed in the next section.

\section{Discussion}

In this paper, the determinants of unemployment duration among the leavers of higher education are analysed using a number of different survival models. Following our econometric estimations and despite a positive sign, hypothesis [H1] is rejected since the estimated coefficient of NAE variable is insignificant. This unexpected result is due to the low variability of the NAE variable. Probably, if we introduce lower educational level this variable will be more significant. However, one can expect that the level of education attainment has a decreasing influence ${ }^{6}$ on employment due to an excess of education offer, unlike the traditional assumption of human capital theory. Concerning remunerations, as expected, higher starting wages motivate individuals to find job. This result confirms hypothesis [H2].

The estimated coefficient of "Gender" variable shows not significant discrimination between men or women of higher education in the professional insertion. This evidence rejects hypothesis [H3].

\footnotetext{
${ }^{5}$ Not displayed but available under request from the authors.

${ }^{6}$ Which questions the traditional assumption of human capital theory (see section 2).
} 
However, discrimination for lower educational attainment may appear: Unfortunately, we cannot test this hypothesis with our data.

Relative to the hypothesis [H4], overeducation variable is positively and statistical significant on all Cox models meaning that it decreases the probability to find job. Therefore, hypothesis [H4] is rejected. As evoked by Dolton and Silles (2003), overeducated workers are not randomly selected and they have probably lesser academic results. In other words, overeducated people probably have the lesser potential of productivity and, consequently, they have more difficulties to find a job. In consequence, employers seem to pay a strong attention to the schooling results rather than the educational level attainment.

Additional, PS - public employment - is negative but statistical insignificant and therefore we do not accept hypothesis [H5]. The prospect to become civil servant is not much longer than to be employed in the private sector.

Searching for a job is, obviously, a behaviour that decreases unemployment duration since the correspondent estimated coefficient is negative and statistical significant, validating hypothesis [H6]. This result confirms that this behaviour is an indicator for the employers of the individual motivation. Hence, employment offices probably stimulate the individual in this job prospect (Gorter and Kalb, 1996).

Past jobs seem not to decrease unemployment duration since this variable is negative but insignificant. One explanation is that this employment is, essentially, student jobs with low qualification level requirement. Therefore, employers do not take into account these past jobs in their recruitment, testifying our insignificant result. So, hypothesis seventh is not validated. Additional stage decreases the unemployment duration in model (M1) to (M3), but rise the unemployment duration in model (M4) and (M5), which still confirms the rejection of hypothesis [H7].

ES is positive meaning that exact science increases unemployment duration. However, this variable turns negative on model (M4). NS is negatively and statistical significant, meaning that training in natural science decreases unemployment duration, like HS estimated coefficient. Therefore, the faculty of training is a major determinant of the professional insertion and confirms assumption [H8]. The advantage in professional insertion in the human science - in contrast to the social science - can be explained by the evolution of student number by faculty. As evoked by Diebolt and El Murr (2003), humanity sciences were, twenty years ago, were taught in faculties with poor perspectives of professional career. Consequently, students have favoured their educational choice for social and exact sciences. Finally, today, a glutting of student number in these faculties is observed. In other 
words, skills offered in ES (and social science) exceed the demand of the correspondent activity sectors of labour market. Furthermore, there are some evidences of biased technical progress that favour exact sciences in the 80's, with the computing evolution (Haskel and Heden, 1999), whereas in the late 90's this demand effect is less strong (Guironnet, 2006).

$\mathrm{EF}$ and EM variables have mixed insignificant results: executive father has a negative effect on unemployment only in model (M3) and the coefficient of executive mother is negative only for model (M2) and (M3). Therefore, hypothesis [H9] is rejected: professional activities of the parents are insignificant; they do not influence the professional insertion of their child. ${ }^{7}$

Vocational degrees increase unemployment duration. In France, vocational trainings are the weaker degrees in higher education and employers have negative opinions about this training. Obviously, hypothesis [H10] is rejected and confirms the result of Eyal and Beenstock (2008).

Medium and large firms both increase the unemployment duration, therefore hypothesis [H11] is accepted. An individual must search for a job in small firms to quickly get a job.

Lastly, hypothesis [H12] is rejected. National service in army reduces the unemployment duration. As this status is not considered as unemployment, this variable obviously reduces the unemployment duration statistically. However, it is not a proof that this variable favours employment. It will be more realistic to think the contrary as stipulated by hypothesis [H12].

\section{Summary and Conclusions}

The main result of our study is that the choice of a faculty has more influence than the level of education attainment in the professional insertion. In France, the large increase in the number of students in the educational system has produced a dimishing trend in the job access for a given educational level. Today, a feasible recommendation for policy-makers in education is to stress the education offer to the demand of labour market, as suggested by the overeducation literature. This policy should improve professional insertion of the young cohorts of graduates. Concerning overeducation phenomenon, the result should be interpreted with caution: if it suggests that student must choose their training only in respect of labour market requirement, others researches are needed; overeducation could represent an advantage in the development of professional careers (Groeneveld and Hartog, 2004). However, our study confirms the significance of overeducation variable in analyse on unemployment duration.

\footnotetext{
${ }^{7}$ This fact not exclude that an executive parents could affect the educational choice of children.
} 
Additionally, it is more difficult to find a job after leaving a faculty with a glutting of student number. Under perfect information, individuals must choose their faculty in function of the differential between demand of labour market and the number of students enrolled in the correspondent initial training. Moreover, students must avoid have a temporary job during their courses. For policy implications, government should revalorize the vocational training to improve the efficiency in the allocation of human resources (Béduwé and Planas, 2004).

\section{Acknowledgements}

Comments by two anonymous referees as well as from Patrice Bougette are gratefully acknowledged. 


\section{Appendix}

Table 3. Affichard's Matches Grid

\begin{tabular}{|l|c|c|c|}
\hline Occupation/Degree & Business school, Master 2 & Master 1, Licence & 2 years in higher education \\
\hline Executive, Engineer & Adequately & Adequately & Undereducated \\
\hline Intermediate profession & Overeducated & Adequately & Adequately \\
\hline Technician & Overeducated & Overeducated & Adequately \\
\hline Skilled employee & Overeducated & Overeducated & Overeducated \\
\hline Unskilled employee & Overeducated & Overeducated & Overeducated \\
\hline Skilled worker & Overeducated & Overeducated & Overeducated \\
\hline Unskilled worker & Overeducated & Overeducated & Overeducated \\
\hline
\end{tabular}




\section{References}

Addison, J.T. and Portugal, P. (2003), Unemployment Duration: Competing and Defective Risks, Journal of Human Resources, 38, 156-191.

Affichard, J. (1981), "Quels emplois après l'école : la valeur des titres scolaires depuis 1973", Économie et Statistique, 173, 7-26.

Anderson, G.M.; Halcoussis, D. and Tollison, R.D. (1996) Drafting the competition: Labor unions and military conscription. Defence and Peace Economics, 7, 189-202.

Andrén, T. and Andrén, D. (2006). Assessing the employment effects of vocational training using a one-factor model. Applied Economics, 38, 2469-2486.

Audas, R.; Berde, E. and Dolton, P. (2005) Youth Unemployment and Labour Market Transitions in Hungary. Education Economics, 13, 1-25.

Barros, C.P., Passos, J. and Gil-Alana, L. A. (2005), The Timing of ETA Attacks. Journal of Police Modelling, 28, 335-46.

Battu, H.; Belfield, C.R. and Sloane, P.J. (1999). Overeducation Among Graduates: a cohort view. Education Economics, 7, 21-38.

Bazen, S. and Martin, J.P. (1991), The Impact of the Minimum Wage on Earnings and Employment in France. OECD Economic Studies, 16, 199-221.

Béduwé, C and Planas, J. (2004), The Effects of Educational Expansion on the Functioning of the Labour Market: Report of a Comparative Study. Compare, 34, 53-73.

Budria, S. and Pereira, P.T. (2007). The wage effects of training in Portugal: differences across skill groups, genders, sectors and training types. Applied Economics, 39, 787-807.

Collier, W. (2005), Unemployment Duration and Individual Heterogeneity: a Regional Study. Applied Economics, 37, 133-53.

Cox, D.R. and Oakes, D. (1984), Analysis of Survival Data. London, UK: Chapman and Hall/CRC Press.

Cueto, B. and Mato, J. (2006), An Analysis of Self-Employment Subsidies with Duration Models. Applied Economics, 38, 23-32. 
Diebolt, C. and El Murr, B. (2003), A Model of Glutting. Human Capital and Labour Markets in the Long Run. Applied Economics Letters, 10, 557-560.

Dolton, P. and Silles, M. (2003), The Determinants and Consequences of Graduate Over-Education. In Büchel F., de Grip A. \& Mertens A. (eds), Overeducation in Europe: Current Issues in Theory and Policy, Edward Elgar, Cheltenham, 189-216.

Dupray, A. (2001), The Signalling Power of Education by Size of Firm and the Long Term Effects on Workers Career. International Journal of Manpower, 22, 13-38.

Eyal, Y. and Beenstock, M. (2008), Sign Reversal in LIVE Treatment Effect Estimates: The Effect of Vocational Training on Unemployment Duration. Labour Economics, 15, 1102-1125.

Freeman, R. (1976), The overeducated american. Academic Press, New York.

Gokovali, U. Bahar, O. and Kozak, M. (2006), Determinants of Length of Stay: A Practical Use of Survival Analysis. Tourism Management, 28, 736-746.

Gonzalez, A. and Hilmer, M.J. 2006). The role of 2-years college in improving situation of Hispanic post secondary education. Economics Education Review, 25, 249-257.

Gonzalo, M.T. (2002), A New Look at the UI Effect on Transition from Unemployment into Wage Employment in Spain: The Limited Duration of the UI Benefits Entitlement. Applied Economics, $34,2177-2187$.

Gorter, C., and Kalb, G.R.J. (1996), Estimating the Effect of Councelling and Montoring the Unemployed Using Job Search Model. Journal of Human Resources, 31, 590-610.

Grilli L. (2006), Multilevel Models for the Analysis of the Transition from University to Work. VIII International Meeting on Quantitative Methods for Applied Sciences, Certosa di Pontignano (Siena), 11-13 September.

Groeneveld, S. and Hartog, J. (2004), Overeducation, Wages and Promotions within the Firm. Labour Economics, 11, 701-14.

Guironnet, J-P. (2006), La suréducation en France : Vers une dévalorisation des diplômes du supérieur? Économie Appliquée, 59, 93-120. 
Guironnet, J-P. and Peypoch, N. (2007), Human Capital Allocation and Overeducation: A Measure of French Productivity (1987, 1999), Economic Modelling, 24, 398-410.

Hartog, J. (2000), Overeducation and Earning: Where Are We, Were Should We Go?, Economics of Education review, 19, 131-147.

Haskel J., Heden Y. (1999), Computers and the Demand or Skilled Labour: Industry - and Establishment - Level Panel Evidence for the UK ", The Economic Journal, 454, C68-C79.

Haurin, D.R. and Sridhar, K.S. (2003), Rates on Reservation Wages and Duration of Search a Job. Apllied Economics, 35, 1469-76.

Heywood, J.S. and Wei, X. (2004). Education and Signaling: Evidence from a Highly Competitive Labor Market. Education Economics, 12, 1-16.

Imazeki, J. (2005), Teacher Salaries and Teacher Attrition. Economics of Education Review, 24, 431-449.

Kirby, S.N. Naftel, S. and Berends, M. (1999). Staffing at-Risk School Districts in Texas: Problems and Prospects. Santa Monica, RAND, MR-1083-EDU.

Lancaster, T. (1979), Econometric methods for the duration of unemployment. Econometrica, 47, 939-56.

Lassibile, G. and Gómez, L.N. (2008) Why do Higher Education Students Drop Out? Evidence from Spain. Education Economics, 16, 89-105.

Leung, M.K.; Rigby, D. and Young, T. (2003), Entry of Foreign Banks in the People's Republic of China: A Survival Analysis. Applied Economics, 35, 21-31.

O'Regan, K.M. and Quigley, J.M. (1993), Family Networks and Youth Access to Jobs. Journal of Urban Economics, 34, 230-48.

Prentice, R.L., Williams, B.J. and Petersen, A.V. (1981), On the Regression Analysis of Multivariate Failure Time Data. Biometrica, 68, 157-164.

Prieto-Rodriguez, J. and Rodriguez-Gutierrez, C. (2000) The added worker effect in the Spanish case. Applied Economics, 32, 1917-1925. 
Requena-Silvente, F. and Walker, J. (2005), Competition and Product Survival in the UK Car Market. Applied Economics, 37, 2289-2295.

Russo, G. ; Gorter, C. and Schettkat, R. (2001) Searching, hiring and labour market conditions. Labour Economics, 8, 553-571.

Shauman, K.A. (2005), Occupational Sex Segregation and the Earnings of Occupations: What Causes the Link among College-Educated Workers? Social Science Research, 35, 577-619.

Sloane, P.J., (2003), Much ado about nothing? What does the overeducation literature really tell us? In Büchel F., de Grip A. \& Mertens A. (eds.), Overeducation in europe: Current issues in theory and practice, Edward Elgar, 11-45.

Spence, M., (1973), Job market signaling. Quarterly Journal of Economics, 87, 355-74.

Stinebrickner, T.R. (2002), An Empirical Investigation of Teacher Attrition. Economics of Education Review, 17, 127-136.

Tribó, J.A. (2005), An Analysis of Lengh of labour and Financial Contracts: a Study for Spain. Applied Economics, 37, 905-16.

Vandenberghe, V. (2000) Leaving Teaching in the French - Speaking Community of Belgium: A Duration Analysis. Education Economics, 8, 221-239.

Van Hooft, E.A.J., Born, M.Ph., Taris, T.W. and Van der Flier, H. (2005), Predictors and Outcomes of Job Search Behavior: The Moderating Effects of Gender and Family Situation. Journal of Vocational Behavior, 67, 133-152.

Vega-Cervera, J.A. and Gordillo, I.C. (2001) Duration Analysis Applied to the Adoption of Knowledge. Education Economics, 9, 19-36.

Warner, J.T. and Negrusa, S. (2005) Evasion costs and the theory Of conscription. Defence and Peace Economics, 16, 83-100. 